\title{
THE RADICAL CATION OF BACTERIOCHLOROPHYLL $b$. A LIQUID-PHASE ENDOR AND TRIPLE RESONANCE STUDY
}

\author{
F. LENDZIAN ${ }^{a}$, W. LUBITZ ${ }^{b}$, R. STEINER ${ }^{c}$, E. TRÄNKLE $^{d}$, \\ M. PLATO ${ }^{a}, H$. SCHEER $^{c}$ and K. MÖBIUS ${ }^{a}$ \\ a Instttut für Molekülphysik, Frete Untversität Berln, D-1000 Berlin 33, West Germany \\ ${ }^{b}$ Instıtut für Organische Chemie, Frele Universität Berlın. D-1000 Berlin 33. West Germany \\ c Institut für Botanik, Unwersität München, D-8000 Munich 19, West Germany \\ ${ }^{d}$ Institut für Theorie der Elementarteilchen, Frele Unwersität Berlın, D-1000 Berlin 33, West Germany
}

Received 17 February 1986

\begin{abstract}
The radical cation of bacteriochlorophyll $\mathbf{b}(\mathrm{BChl} \mathbf{b})$ is investigated by ENDOR and TRIPLE resonance in liquid solution. The experimental hyperfine coupling constants, ten proton and three nitrogen couplings, are compared with the predictions from advanced molecular-orbital calculations (RHF INDO/SP). The detailed picture obtained of the spin density distribution is a prerequisite for the investigation of the primary electron donor radical cation in $\mathrm{BChl} b$ containing photosynthetic bacteria.
\end{abstract}

\section{Introduction}

The primary processes of photosynthesis involve light-induced charge separation followed by fast electron transfer reactions $[1,2]$. These reactions take place in the reaction centre ( $\mathrm{RC}$ ), a protein complex [3]. In photosynthetic bacteria the participating molecules are bacteriochlorophylls (BChl), bacteriopheophytins and quinones which are all embedded in the protein matrix [1-3]. For a complete understanding of the primary processes a detailed knowledge about the spatial and electronic structure of these molecules in their ground, excited, and charged radical states is indispensable [3-6].

For the RC of the bacterium Rhodopseudomonas (Rps.) viridis which has recently been crystallized [7], the spatial arrangement of the pigment molecules has been determined by X-ray diffraction [8]. One of the important results of this work is the finding of a bacteriochlorophyll dimer. Such a dimer had been proposed originally for the primary electron donor $P$ on the basis of EPR experiments on $\mathrm{P}^{+}$and $\mathrm{BChl} \mathrm{a}^{+}$. [9] . It has been confirmed later by ENDOR experiments in frozen [10,11] and liquid [12-14] RC solutions. Since so far Rps. viridis is the only organism for which an X-ray structure analysis of the RC was performed, other approaches for the structural characterization of the RC are desirable. For the paramagnetic molecules high-resolution liquid-phase ENDOR in combination with advanced MO calculations represent such an approach [14-16]. The basic procedure is first to elucidate in detail the spin density distribution for the involved molecules in vitro and in vivo [12-14]. These will then be compared with the results of advanced $\mathrm{MO}$ calculations for various possible molecular structures. Criteria for highly probable configurations are the agreement between experimental and theoretical spin densities and the total energy of the system [15]. This method has been applied to the primary electron donor radical cation $\mathrm{P}^{+}$of $\mathrm{BChl}$ a containing bacteria (Rps. sphaeroides and Rhodospirillum rubrum) yielding detailed structural proposals [14-16]. Similar investigations of $R p s$. viridis are particularly important because they directly show whether this procedure gives structural information consistent with an X-ray analysis. Structural information from ENDOR combined with MO theory is of course obtained less directly than that from an X-ray analysis and may be hampered by the problem of uniqueness [15]. However, a great advantage of this method is that single-crystal samples are not required. Primarily the ENDOR experiments 
measure the spatial distribution of the unpaired electron, information which is important for the understanding of electron-transfer processes and which is not obtainable from X-ray data.

Clearly, a detailed investigation of in vitro $\mathrm{BChl} \mathbf{b}^{+}$ is preprequisite for the comparison with the in vivo system. BChl b is chemically very unstable and decomposes rapidly in the presence of light and oxygen $[17,18]$. A rapid decomposition of this bacteriochlorin to products of the chlorin type has also been reported for its radical cation [19]. As a consequence ENDOR experiments have so far been performed on this radical in frozen solution where only part of the hyperfine structure could be resolved [19]. Here, we present a high-resolution electron spin density map for $\mathrm{BChl} \mathbf{b}^{+}$obtained from liquid solution $\mathrm{ENDOR}$ and TRIPLE resonance that agrees well with the results from advanced MO calculations.

\section{Materials and methods}

BChl b was isolated from Rps. viridis after a modified method of Strain and Svec [20]. The crude pig. ment mixture was purified by sucrose chromatography in dim green light. The used solvents as well as the column were saturated with nitrogen and the solvent reservoirs were kept over magnesium hydroxicar. bonate and sodium ascorbate. The isolated $\mathrm{BChl} \mathbf{b}$ was stored under argon below $-20^{\circ} \mathrm{C}$ in the dark.

The radical cation of $\mathrm{BChl} b$ was generated by oxidation with zinc tetraphenylporphin perchlorate $\left(\mathrm{ZnTPP}{ }^{+} \mathrm{ClO}_{4}\right)$. An excess of $\mathrm{BChl} b$ was used to avoid any contributions of the ZnTPP radical cation to the EPR and ENDOR spectra of BChl $\mathbf{b}^{+}$.

In order to avoid further oxidation and isomerization reactions of $\mathrm{BChl} b[18,19]$ the preparation has been carried out in the sample tube inside the ENDOR cavity at $T=220 \mathrm{~K}$ in the dark under argon atmosphere. The sample tube was then closed and the EPR and ENDOR measurements were performed immediately. Under these conditions, the lifetime of the $B C h l b$ radical cation was about half an hour.

The laboratory-built ENDOR and TRIPLE spectrometer has been described $[21,22]$. For a discussion of the potential advantages of the electronnuclear-nuclear triple resonance methods both "special TRIPLE" and "general TRIPLE", the reader is referred to refs. $[23,24]$. s-spin densities and total energies for geometry optimization were calculated by a restricted HartreeFock procedure for doublet states ("half-electron method" by Dewar [25]) using the INDO approximation and parameterization by Pople and Beveridge [26] and a subsequent perturbation treatment of spin polarization cffects (RHF INDO/SP method) [15]. The calculations were performed on a CRAY-1M vector computer of the Konrad Zuse Computer Center of Berlin.

\section{Results and discussion}

The first derivative EPR spectrum of $\mathrm{BChl} \mathbf{b}^{+}$ (fig. 2) consists of a Gaussian line showing no resolved hyperfine structure. The $g$ value $(2.0025 \pm 0.0001)$ is in accordance with earlier results [19]. There is a

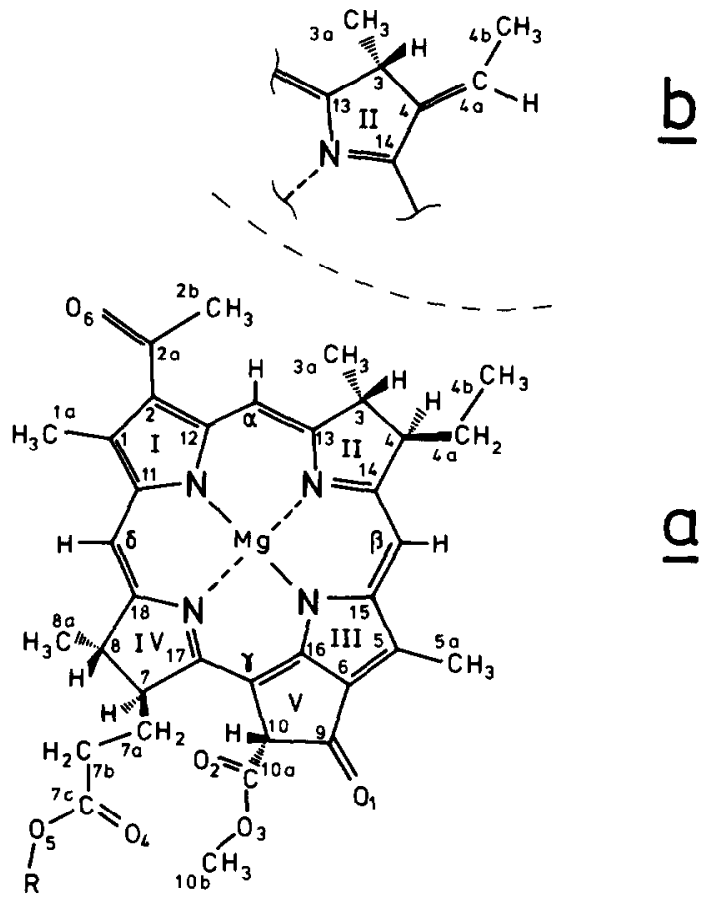

\section{Bacteriochlorophyll}

Fig. 1. Molecular structures and numbering scheme of bacteriochlorophyll a (BChl a) and BChl b. The ethyl group and the proton at position 4 (ring II) in $\mathrm{BChl}$ a are replaced by an ethylidene group in $B C h l b . \mathrm{R}=$ phytyl $\left(\mathrm{C}_{20} \mathrm{H}_{39}\right)$. 


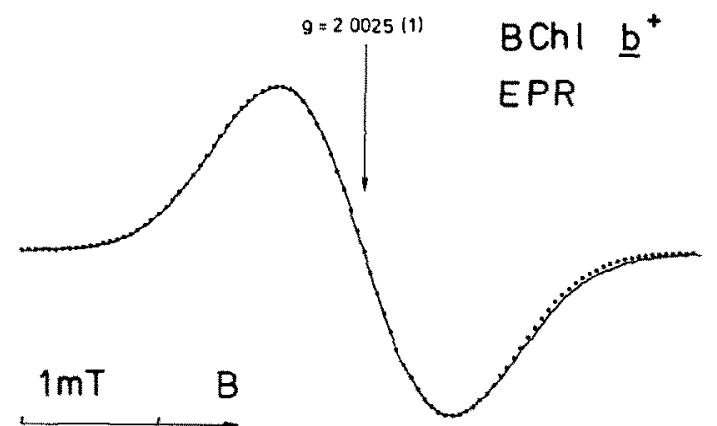

Fig. 2. EPR spectrum of BChl b: in $\mathrm{CH}_{2} \mathrm{Cl}_{2} / \mathrm{CH}_{3} \mathrm{OH}(6: 1)$. Solid line: $T=215 \mathrm{~K}$ (liquid solution); linewidth: $1.26 \pm 0.02$ $\mathrm{mT}(T=215 \mathrm{~K})$; in frozen solution $(T=145 \mathrm{~K}$, spectrum not shown) the linewidth is significantly larger (1.35 \pm 0.02 $m T)$, see text. Dotted line: simulation using the isotropic proton and nitrogen hfes and the assignments given in table 1 .

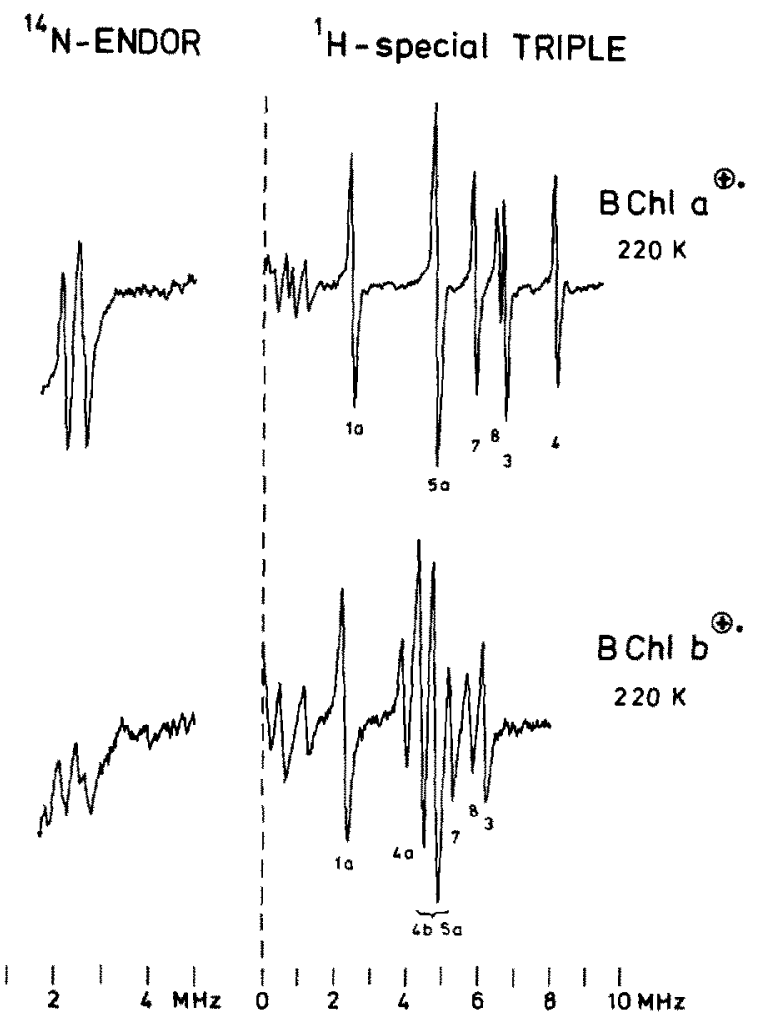

Fig. 3. High-frequency ${ }^{14} \mathrm{~N}$-ENDOR lines $\left({ }^{14} \mathrm{~N}\right.$ Larmor frequency $1.04 \mathrm{MHz}$ ) and proton special TRIPLE spectra of BChl a $a^{+}$and $\mathrm{BChl} \mathrm{b}{ }^{*}$ in $\mathrm{CH}_{2} \mathrm{Cl}_{2} / \mathrm{CH}_{3} \mathrm{OH}$ solution $(6: 1) .{ }^{14} \mathrm{~N}$ spectra: $T=270 \mathrm{~K}, 20 \mathrm{~mW}$ microwave power, $200 \mathrm{~W}$ if power (BChl a. ) and $T=220 \mathrm{~K}, 80 \mathrm{~mW}$ microwave power, $300 \mathrm{M}$ If power (BChl b.). ${ }^{1} \mathrm{H}$ special TRIPLE spectra: $T$ $=220 \mathrm{~K}$, total rf power $200 \mathrm{~W}$, microwave power $20 \mathrm{~mW}$ (BChl $\mathrm{a}^{+}$) and $80 \mathrm{~mW}\left(\mathrm{BChl}^{*}\right)$. noticeable difference between the linewidth in liquid $(\Delta B=1.26 \pm 0.02 \mathrm{mT})$ and frozen solution $(\Delta B=$ $1.35 \pm 0.02 \mathrm{mT}$ ). This must be due to $g$ and/or hyperfine anisotropy. The observed EPR linewidth in frozen solution is in agreement with values reported earlier [19].

Liquid solution ${ }^{14} \mathrm{~N}$ ENDOR and proton special TRIPLE spectra of $\mathrm{BChl}^{\mathbf{b}^{+}}$and $\mathrm{BChl} \mathrm{a}^{+}$are shown in fig. 3. In the special TRIPLE experiment the highand low-frequency NMR transitions of a particular nucleus are irradiated simultaneously. Thereby the signal intensity and the resolution can be increased as compared with an ENDOR experiment. The frequency axis gives the deviation from the proton Larmor frequency which is equivalent to one-half of the respective hyperfine coupling constant ( $\mathrm{hfc}$ ) [23, $24]$.

Ten proton lines and three ${ }^{14} \mathrm{~N}$ lines are resolved in the spectra. The corresponding hfos are listed in table 1 .

An assignment of the hfos to molecular positions in $\mathrm{BChl}^{\mathbf{b}^{+}}$can be accomplished on the basis of experimental evidence and/or by comparison with MO calculations. It is well known that ENDOR line intensities do not directly reflect the number of con. tributing nuclei because the individual nuclear relaxation behaviour determines the line intensity to a large extent $[23,29]$. This causes assignment problems which can of ten be overcome by applying the special TRIPLE resonance technique where the line intensities do reflect the number of contributing nuclei provided the electronic relaxation rates dominate the nuclear relaxation rates $[23,24]$. For photosynthetic pigments this was demonstrated in the special TRIPLE spectra of bacteriochlorophyll a, chlorophyll a and their pheophytin a radical anions [30-33]. In the proton special TRIPLE spectrum of $B C h 1 \mathbf{b}^{+}$the three intense lines (corresponding hfes: $4.70,8.95$ and 9.70 $\mathrm{MHz}$ ) can therefore be assigned to the methyl protons at positions $1 \mathrm{a}, 4 \mathrm{~b}$ and $5 \mathrm{a}$ (fig. 1).

Further aid in the assignment is provided by the signs of the hfcs because - for positive carbon $\pi$-spin densities - positive $h f c s$ are expected for $\beta$-protons and negative hfcs for $\alpha$-protons (for the characteriza. tion of $\beta$ - and $\alpha$-protons see ref. [34]). Relative signs of the hfcs can be obtained applying the general TRIPLE resonance technique where a particular NMR transition is pumped with a second strong unmodu- 
Table 1

Hyperfine coupling constants (hfcs) in MHz of BChl $\mathbf{a}^{+}$and $\mathrm{BChl} \mathbf{b}^{\ddagger}$. Experimental hfcs derived from ENDOR/TRIPLE in liquid solution, signs obtained from general TRIPLE resonance (see text). Theoretical values derived from MO calculations (see text)

\begin{tabular}{|c|c|c|c|c|c|}
\hline \multirow[t]{2}{*}{ Nucleus } & \multirow[t]{2}{*}{ Position c) } & \multicolumn{2}{|l|}{$\left.\mathrm{BChl} \mathrm{a}^{+} \mathrm{a}\right)$} & \multicolumn{2}{|l|}{ BChl b: b)' } \\
\hline & & exp. hfc & theoret. hfc d) & exp. hfc & theoret. hfc d) \\
\hline$\beta-H$ & $\begin{array}{l}3 \\
4 \\
7 \\
8\end{array}$ & $\begin{array}{l}+13.47 \\
+16.35 \\
+13.11 \\
+11.76\end{array}$ & $\begin{array}{l}+13.93 \\
+16.31 \\
+13.79 \\
+12.79\end{array}$ & $\begin{array}{c}+12.45 \\
- \\
+11.60 \\
+10.55\end{array}$ & $\begin{array}{c}+14.67 \\
- \\
+14.16 \\
+13.00\end{array}$ \\
\hline $\mathrm{CH}_{3}$ & $\begin{array}{l}1 a \\
4 b \\
5 a\end{array}$ & $\begin{array}{l}+4.93 \\
+9.62\end{array}$ & $\begin{array}{l}+3.73 \\
+0.13 \\
+7.32\end{array}$ & $\begin{array}{l}+4.70 \\
+8.95 \\
+9.70\end{array}$ & $\begin{array}{l}+3.60 \\
+6.46 \\
+6.91\end{array}$ \\
\hline$\alpha-H$ & $\begin{array}{l}4 \mathrm{a} \\
\alpha \\
\beta \\
\delta\end{array}$ & $\left.\begin{array}{r}-0.55 \\
+2.35 \\
+1.30\end{array}\right\}$ & $\begin{array}{l}-0.52 \\
+1.61 \\
+0.91 \\
+1.35\end{array}$ & $\begin{array}{c}-8.02 \\
+2.50 \\
\left\{\begin{array}{c}1.20 \mathrm{e})\end{array}\right.\end{array}$ & $\begin{array}{l}-4.22 \\
+1.43 \\
+0.83 \\
+1.23\end{array}$ \\
\hline $\begin{array}{l}\text { other } \\
\text { H }\end{array}$ & $\begin{array}{c}10 \\
2 b \\
3 a \\
7 a \\
8 a\end{array}$ & $\left.\begin{array}{r}-1.64 \\
-0.15 \\
\{-0.55\end{array}\right\}$ & $\begin{array}{l}-2.80 \\
-0.26 \\
-0.87 \\
-1.13 \\
-0.81\end{array}$ & $\begin{array}{l}1,20 \mathrm{e}) \\
0.40 \mathrm{e})\end{array}$ & $\begin{array}{l}-2.74 \\
-0.29 \\
-0.82 \\
-1.53 \\
-0.82\end{array}$ \\
\hline${ }^{14} \mathrm{~N}$ & $\begin{array}{l}\text { I } \\
\text { II } \\
\text { III } \\
\text { IV }\end{array}$ & $\begin{array}{l}-2.35 f) \\
-3.17 \\
-2.35 f) \\
-3.05\end{array}$ & $\begin{array}{l}-1.84 \\
-2.32 \\
-2.20 \\
-2.31\end{array}$ & $\begin{array}{l}2.3 \\
3.3 \\
2.3 \\
3.0\end{array}$ & $\begin{array}{l}-1.68 \\
-2.22 \\
-2.07 \\
-2.11\end{array}$ \\
\hline
\end{tabular}

a) $T=220 \mathrm{~K}$ for protons $(22,33), T=270 \mathrm{~K}$ for nitrogens.

b) $T=220 \mathrm{~K}$ for protons and nitrogens.

c) See molecular structure fig. 1. Note different substituents at positions $4 \mathrm{a}$ and $4 \mathrm{~b}$ in $\mathrm{BChl}$ a and BChl b. For BChl $\mathrm{a}^{+}$the groups of $\beta$-Hs at positions $3,4,7,8$, of $\mathrm{CH}_{3}$ protons at positions $1 \mathrm{a}, 5 \mathrm{a}$ and of $\mathrm{Hs}$ in positions $2 \mathrm{~b}, 3 \mathrm{a}, 4 \mathrm{a}, 7 \mathrm{a}$ and $8 \mathrm{a}$, have been assigned by selective deuteration. The proton at position 10 was identified by proton/deuteron exchange experiments [22,27]. Specific assignments within these groups of protons are based on comparison with the calculations.

d) RHF-INDO/SP method, $Q$ factors relating s-spin densities and isotropic hfcs (MHz), see fig. 4 .

e) No signs could be determined for these hfes because several protons having hfcs of almost identical magnitude but with different signs contribute to the corresponding ENDOR lines.

f) Two nitrogens must be assigned to this hfc as shown by ${ }^{15} \mathrm{~N}-\mathrm{ENDOR}$ experiments [28].

lated rf field while recording the ENDOR spectrum [23]. Depending on the relative signs of the hfcs, changes of the signal intensities relative to the normal ENDOR spectrum are detected [23]. Using this technique we obtained a negative sign only for the hfc of $8.02 \mathrm{MHz}$, the large methyl hfcs taken as positive. This differs from our results for $\mathrm{BChl} \mathrm{a}^{+}$where no large negative $\mathrm{hfc}$ was observed. We therefore assign this hfc to the $\alpha$-proton of the ethylidene group at ring II (position 4a, fig. 1). From a comparison with $\mathrm{BChl} \mathrm{a}^{+}[22,27]$ the three largest positive proton $\mathrm{hfcs}$ are attributed to the $\beta$-protons at rings II and IV (positions 3,7 and 8 , fig. 1 ).

The assignment of the three small proton hfcs $(0.4$, 1.2 and $2.5 \mathrm{MHz}$ ) given in table 1 is solely based on $\mathrm{MO}$ calculations. For $\mathrm{BChl} \mathrm{a}^{+}$we could achieve a definite assignment also for the small hfes by isotopic labelling and proton/deuteron exchange experiments $[22,27]$.

The instability of $\mathrm{BChl} b$ and its radical cation was a serious problem for our experiments. To ensure that no decomposition products gave rise to additional ENDOR or TRIPLE lines, general TRIPLE resonance was used. In this experiment changes of 
line intensities are expected only for those ENDOR lines stemming from one particular paramagnetic species $[21,23]$. We observed significant general TRIPLE effects for all proton ENDOR lines of our $\mathrm{BChl} \mathrm{b}^{+}$spectrum except for those corresponding to the two smallest proton hfcs ( 0.4 and $1.2 \mathrm{MHz})$. Several protons having positive and negative signs of their hfes might, however, contribute to these two lines in which case the overall TRIPLE effect would vanish. The MO calculations predict indeed eight proton hfcs in the range between +1.5 and $-2.7 \mathrm{MHz}$ (see table 1). Furthermore, a paramagnetic decomposition product of $\mathrm{BChl} b$ is expected to have not only two such small proton hfes.

Using an excess of $\mathrm{ZnTPP}^{+} \mathrm{ClO}_{4}^{-}$for oxidizing $\mathrm{BChl} \mathbf{b}$ we could, in the presence of light and traces of oxygen, obtain such a paramagnetic decomposition product having an EPR linewidth $\Delta B \approx 0.9 \mathrm{mT}$. This product has been attributed earlier to a chlorin deriva. tive with a structure similar to chlorophyll a [19] . The special TRIPLE spectrum obtained from this species was indeed very similar to that of the plant chlorophyll a radical cation $[22,35]$, and none of the observed lines were coincident with those of $\mathrm{BChl}^{\mathbf{b}} \mathbf{b}^{+}$. This product was, however, not observed when light, oxygen and an excess of $\mathrm{ZnTPP}^{+} \mathrm{ClO}_{4}^{-}$were rigorously excluded.

The similarity of the hfcs found for $\mathrm{BChl} \mathrm{b}^{+}$with those of $\mathrm{BChl} \mathrm{a}^{+}$, the occurrence of an additional methyl proton line and, in particular, the large negative $\mathrm{hfc}(-8.02 \mathrm{MHz})$, which is also predicted by the MO calculations, make it very probable that the observed spectra really arise from the $\mathrm{BChl} \mathbf{b}$ radical cation.

We have also detected three ${ }^{14} \mathrm{~N}$ ENDOR lines for $\mathrm{BChl} \mathbf{b}^{+}$(fig. 3). The absolute values of the corresponding $\mathrm{hfcs}$ are again very similar to those of $\mathrm{BChl}$ $\mathrm{a}^{+}$(see table 1). Their signs could, however, not be determined due to the rather poor signal-to-noise ratio. In analogy to $\mathrm{BChl} \mathrm{a}^{+}$, two ${ }^{14} \mathrm{~N}$ nuclei may be assigned to the smallest $\mathrm{hfc}$ (for BChl $\mathrm{a}^{+}$this has been verified by ${ }^{15} \mathrm{~N}$-ENDOR [28]).

The four proton hfcs found in earlier ENDOR experiments on $B C h l b^{\dagger}$ in frozen solution $(1.12,4.76$, 8.96 and $12.88 \mathrm{MHz}$ [19]) agree satisfactorily with some of our hfes measured in liquid solution. However, our assignment, based on TRIPLE experiments, sign determination and comparison with advanced

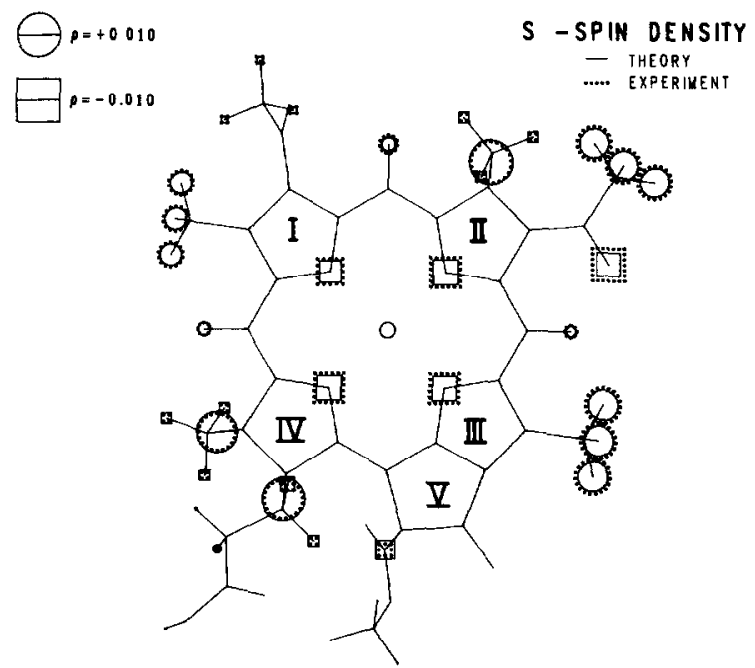

Fig 4. Comparison of experimental (dotted) and calculated (solid lincs) s-spin densities $\rho$ for the BChl b radical cation. Their values are proportional to the area of the squares $(\rho$ $<0)$ and circles $(\rho>0)$, respectively. For the calculation the RHF INDO/SP method was used (see text). The full molecular structure was taken except for a truncation of the isoprenoid chain $R$ at position $0-5$ (fig. 1) [15] . Mostly standard bond lengths and angles were employed [15], atomic positions for ring $\mathrm{V}$, the methyl groups (rings I and III), the acetyl group (ring I) and the ethylidene group (ring II) were determined by energy minimization. Thereby the acetyl group (ring I) was found to be $105^{\circ}$ out-of-plane (dihedral angle with respect to positions $C-1, C-2, C-2 a$ and $0-6$, see fig. 1) due to steric hindrance. The ethylidene group (ring II) stayed approximately in the plane of the porphyrin system in spite of steric hindrance, because of the double bond between carbon positions 4 and $4 a$. Experimental values from isotropic hfes (table 1 ) by use of: $Q(\mathrm{H})=1420 \mathrm{MHz}, Q\left({ }^{14} \mathrm{~N}\right)=663$ $\mathrm{MHz}[15]$.

MO calculations, is different. The absolute value of the $\mathrm{hfc}$ of the ethylidene $\alpha$-proton (4a, fig. 1) is much larger $(-8.02 \mathrm{MHz})$ than was assumed in the earlier work $(-4.8 \mathrm{MHz})$. Furthermore, the $\beta$-protons at rings II and IV (pos. 3, 7 and 8, fig. 1) have hfcs of only $10.55,11.6$, and $12.45 \mathrm{MHz}$. There are no proton hfcs as large as $16.8 \mathrm{MHz}$ in $\mathrm{BChl} \mathbf{b}^{+}$, as was assumed in [19] to account for the EPR linewidth. The observed difference between the EPR linewidth of $\mathrm{BChl} \mathbf{b}^{+}$in liquid and frozen solution (fig. 2) is probably mainly caused by the anisotropy of the large $\alpha$-proton hfc at position 4a which gives rise to line broadening in randomly oriented rigid samples. With the hfes and assignments given in table 1 the EPR spectrum of $\mathrm{BChl}$ 
$\mathbf{b}^{+}$in liquid solution could be perfectly simulated (fig. 2, dotted line).

Comparing the corresponding hfes of $\mathrm{BChl}^{+}$and $\mathrm{BChl} \mathrm{a}^{+}$(table 1) one finds almost no change for the methyl protons 1a and 5a (fig. 1). The couplings of the $\beta$-protons of rings II and IV $[3,7,8]$ are reduced by only $10 \%$, and in the region of small proton hfcs $(|a|<2.5 \mathrm{MHz})$ some ENDOR lines may have merged together so that for $\mathrm{BChl} \mathbf{b}^{+}$only three proton hfcs are observed in this region. The major difference arises from the ethylidene substituent at ring II in $\mathrm{BChl} \mathbf{b}^{+}$, which obviously carries large $\pi$-spin density. For the $\alpha$-proton (4a) and for the methyl protons (4b) comparable large $h f c s$ are observed. The detailed picture of the spin density distribution reveals a close similarity of the highest occupied orbitals of $\mathrm{BChl} \mathbf{a}^{+}$and BChl $\mathbf{b}^{+}$(see table 1).

The magnitudes and spectral assignments of the hfcs are in good agreement with predictions from our MO calculations [15] presented in table 1. Fig. 4 shows a graphical comparison between calculated and experimental s-spin densities. The agreement between experimental and calculated results is better than that reported earlier for bacteriochlorophyll radicals [19, 36-38] using other MO methods like PPP [39] or an "ab initio" molecular fragment method [40] which only calculate $\pi$-spin densities.

The investigation of the primary electron donor radical cation $\mathrm{P}_{960}^{+}$in the BChl b containing bacterium Rps. viridis is of special interest for the following reasons: The X-ray structure analysis of RC single crystals of this species clearly reveals $P_{960}$ as a BChl b dimer [8]. However, the EPR linewidth of $P_{960}^{+}$is not narrowed by the factor $2^{-1 / 2}$ as compared to that of the monomer $\mathrm{BChl} \mathbf{b}^{+}$. This is in contrast to the findings for the $\mathrm{BChl}$ a systems $[9,10]$, where this narrowing of the linewidth by $2^{-1 / 2}$ has been explained by an equal sharing of the unpaired electron between two BChl a molecules [9]. This interpretation has been supported by ENDOR experiments on the primary donor $\mathrm{P}_{860}^{+}$in liquid and frozen solutions [1014].

Recently, we have started ENDOR experiments on $\mathrm{P}_{960}^{+}$in liquid solution [16] which suggests an unequal sharing of the unpaired electron between the dimer halves. To support this idea, an unambiguous assignment of at least some of the signals will be necessary, e.g., from specifically dueterated RCs. Work along these lines is in progress.

\section{Acknowledgement}

The authors thank Dr. A.J. Hoff (Huygens Laboratory, State University of Leyden, The Netherlands) who was involved in early stages of this work. This work was supported by the Deutsche Forschungsgemcinschaft (Sfb 161 and Sfb 143).

\section{References}

[1] M.Y. Okamura, G. Feher and N. Nelson, in: Photosynthesis: energy conversion by plants and bacteria, Vol. 1, ed. Govindjee (Academic Press, New York, 1982) p. 195.

[2] F.K. Fong, Light reaction path of photosynthesis (Springer, Berlin, 1982).

[3] G. Feher and M.Y. Okamura, in: The photosynthetic bacteria, eds. R.K. Clayton and W.R. Sistrom (Plenum Press, New York, 1978) p. 349.

[4] B. Chance, D. DeVault, H. Frauenfelder, R.A. Marcus, J.R. Schrieffer and N. Sutin, eds., Tunneling in biological systems (Academic Press, New York, 1979).

[5] A.J. Hoff, Phys. Rept. 54 (1979) 75.

[6] A.J. Hoff, Biophys. Struct. Mech. 8 (1982) 107.

[7] H. Michel, J. Mol. Biol. 158 (1982) 567.

[8] J. Deisenhofer, O. Epp, K. Miki, R. Huber and H. Michel, J. Mol. Biol. 180 (1984) 385.

[9] J.R. Norris, R.A. Uphaus, H.L. Crespi and J.J. Katz, Proc. Natl. Acad. Sci. US 68 (1971) 625.

[10] G. Feher, A.J. Hoff, R.A. Isaacson and C.C. Ackerson, Ann. NY Acad. Sci. 244 (1975) 239.

[11] J.R. Norris, H. Scheer, M.E. Druyan and J.J. Katz, Proc. Natl. Acad. Sci. US 71 (1974) 4897.

[12] F. Lendzian, W. Lubitz, H. Scheer, C. Bubenzer and K. Möbius, J. Am. Chem. Soc. 103 (1981) 4635.

[13] W. Lubitz, F. Lendzian, H. Scheer, M. Plato and K. Möbius, in: Photochemistry and photobiology, Proceedings of the International Conference, University of Alexandria, Egypt, ed. A.H. Zewail (Harwood, New York, 1983) p. 1057.

[14] W. Lubitz, F. Lendzian, H. Scheer, J. Gottstein, M. Plato and K. Möbius, Proc. Natl. Acad. Sci. US 81 (1984) 1401.

[15] M. Plato, E. Tränkle, W. Lubitz, F. Lendzian and K. Möbius, Chem. Phys., submitted for publication.

[16] W. Lubitz, F. Lendzian, M. Plato, K. Möbius and E. Tränkle, in: Antennas and reaction centers of photosynthetic bacteria - structure, interactions and dynamics, ed. M.E. Michel-Beyerle (Springer, Berlin, 1985) p. 164.

[17] R. Steiner, Ph.D. Thesis, Botanisches Institut, Universität München, Munich (1984).

[18] R. Steiner, E. Cmiel and H. Scheer, Z. Naturforsch. 38c (1983) 748 . 
[19] M.S. Davis, A. Forman, L.K. Hanson, J.P. Thornber and J. Fajer, J. Phys. Chem. 83 (1979) 3325.

[20] H.H. Strain and W.A. Svec, in: The chlorophylls, eds. L.P. Vernor and G.R. Seely (Academic Press, New York, 1966).

[21] K. Möbius, M. Plato and W. Lubitz, Phys. Rept. 87 (1982) 171.

[22] F. Lendzian, Ph.D. Thesis, Department of Physics, Freie Universität Berlin, Berlin (1982).

[23] K. Möbius and R. Biehl, in: Multiple electron resonance spectroscopy, eds. M.M. Dorio and J.H. Freed (Plenum Press, New York, 1979) p. 475.

[24] K.P. Dinse, R. Biehl and K. Möbius, J. Chem. Phys. 61 (1974) 4335.

[25] M.J.S. Dewar, J.A. Hashmall and C.G. Venier, J. Am. Chem. Soc. 90 (1968) 1953.

[26] J.A. Pople and D.L. Beveridge, Approximate molecular orbital theory (McGraw-Hill, New York, 1970).

[27] W. Lubitz, F. Lendzian, M. Plato, H. Scheer and K. Möbius, to be published.

[28] W. Lubitz, R.A. Isaacson, E.C. Abresch and G. Feher, Proc. Natl. Acad. Sci. US 81 (1984) 7792.

[29] M. Plato, W. Lubitz and K. Möbius, J. Phys. Chem. 85 (1981) 1202.
[30] W. Lubitz, F. Lendzian and K. Möbius, Chem. Phys. Letters 81 (1981) 235.

[31] W. Lubitz, F. Lendzian and K. Möbius, Chem. Phys. Letters 84 (1981) 33.

[32] A.J. Hoff, F. Lendzian, K. Möbius and W. Lubitz, Chem. Phys. Letters 85 (1982) 3.

[33] F. Lendzian, W. Lubitz and K. Möbius, Chem. Phys. Letters 90 (1982) 375.

[34] A. Carrington and A.D. McLachlan, Introduction to magnetic resonance (Harper and Row, New York, 1969).

[35] M. Huber, F. Lendzian, W. Lubitz, E. Tränkle and K. Möbius, Chem. Phys. Letters, to be published.

[36] J. Fajer, A. Forman, M.S. Davis, L.D. Spaulding, D.C. Brune and R.H. Felton, J. Am. Chem. Soc. 99 (1977) 4134.

[37] J.D. Petke, G.M. Maggiora, L.I. Shipman and R.E. Christoffersen, Photochem. Photobiol. 33 (1981) 663.

[38] J.D. Petke, G.M. Maggiora, L.L. Shipman and R.E. Christoffersen, Photochem. Photobiol. 31 (1980) 243.

[39] R. Pariser and R.G. Parr, J. Chem. Phys. 21 (1953) 466.

[40] R.E. Christoffersen, D.W. Genson and G.M. Maggiora, J. Chem. Phys. 54 (1971) 239. 